J. Clin. Chem. Clin. Biochem.

Vol. 23, 1985, pp. $841-844$

\title{
Determination of Haemoglobin in Gastric Aspirates
}

\author{
By J. H. P. Wilson, H. Koole-Lesuis, A. Edixhoven-Bosdijk, J. W. O. van den Berg and H. A. van Essen ${ }^{1}$ ) \\ Department of Internal Medicine II, University Hospital Dijkzigt, Rotterdam, The Netherlands
}

(Received June 7/August 23, 1985)

\begin{abstract}
Summary: The haemoglobin content of gastric aspirates can be quantitated by conversion of non-fluorescent haem to fluorescent porphyrins by heating gastric aspirates with oxalic acid and ferrous sulphate. Recovery of haemoglobin added to gastric aspirates was $92 \pm 9 \%$, variation coefficient, $n=52$, day to day variation less than $8 \%$. This method was used to calculate blood (haemoglobin) loss in 211 (24 hours) gastric aspirates obtained from 58 intensive care patients. Gastric blood loss was also measured by the ${ }^{51} \mathrm{Cr}$ radiolabelled erythrocytes method in the same samples. There was a good linear correlation $(r=0.942, p<0.001)$ between the two methods. The fluorimetric method of quantitating haem is therefore suitable for detecting and measuring blood loss in gastric contents.
\end{abstract}

\section{Bestimmung von Hämoglobin in Magensaftaspiraten}

Zusammenfassung: Der Hämoglobingehalt von Magensaftaspiraten kann bestimmt werden, indem nichtfluoreszierendes Häm durch Erwärmen der Aspirate mit Oxalsäure und Eisen-II-sulfat in fluoreszierende Porphyrine umgesetzt wird. $\mathrm{Zu}$ Magensaftaspiraten zugesetztes Hämoglobin lieferte eine Ausbeute von $92 \pm 9 \%$ $(n=52)$. Die von Tag zu Tag-Variationen der Messungen lagen unter $8 \%$. Diese Methode wurde zur Schätzung des Blut- (bzw. Hämoglobin-) verlustes in 211 Magensaftproben (24 Stundenaspirate) von 58 Intensivpatienten angewendet. Der Blutverlust über den Magen wurde in den gleichen Proben mit Hilfe ${ }^{51} \mathrm{Cr}-$ markierter Erythrocyten gemessen. Bei Vergleich beider Methoden ergab sich eine gute lineare Korrelation $(r=0,942, p<0,001)$. Die hier beschriebene Methode zur Messung von Hämoglobin mittels fluoreszierender Porphyrine ist daher zum Nachweis von Blut in Magensaftproben geeignet.

\section{Introduction}

The determination of haemoglobin in gastric aspirates has been used in several studies to detect upper gastrointestinal bleeding $(1-4)$. In most studies a peroxidase assay, using guaiacol or $o$-tolidine, has been used. Such leuko dye tests are qualitative rather than quantitative, and have been shown to be unreliable tests for occult blood in gastric juice (5). A reliable alternative is the quantitative measurement of ${ }^{51} \mathrm{Cr}$ radiolabelled erythrocytes. This method is

\footnotetext{
1) Present address: Department of Internal Medicine, St Clara Hospital, Rotterdam, The Netherlands.
}

however costly, invasive and not suitable for routine use. Recently Schwartz et al. $(6,7)$ described a method for measuring haemoglobin in faeces which is based on the removal of iron from haem by heating under reducing acid conditions to convert it to fluorescent porphyrin. This test, which is based on methods described for whole blood and tissues (8), has been shown to be quantitative and specific over a wide range of haemoglobin concentrations in faeces (6). We have applied a modification of their method to the determination of haemoglobin in gastric aspirates, and compared the results obtained by this method to those obtained by ${ }^{51} \mathrm{Cr}$-labelling of the patient's erythrocytes. 


\section{Materials and Methods}

Gastric aspirates were obtained from a series of adult intensive care patients participating in a double-blind, placebo-controlled study of the effects of prostaglandin $E_{2}$ on the occurrence of upper gastrointestinal haemorrhage in intensive care patients. Details of the patients and of the protocol have been described elsewhere (9). Briefly, either placebo or prostaglandin $E_{2}$ was introduced into the stomach by a nasogastric tube at 4 hourly intervals, and gastric contents allowed to drain by gravity between administrations. Gastric contents were kept at $4^{\circ} \mathrm{C}$ until 24 hour collections could be pooled, after which the 24 hour collections were kept at $-20^{\circ} \mathrm{C}$. A total of 211 samples obtaincd from 58 patients were available for both the ${ }^{51} \mathrm{Cr}$ labelled erythrocytes procedure and the chemical analysis. This study was approved by the Medical Ethics Committee of the University Hospital of Rotterdam.

\section{${ }^{s 1} \mathrm{Cr}$ chromate labelling}

Blood $(10 \mathrm{ml})$ was withdrawn from the patient, the erythrocytes were labclled with $1.11 \mathrm{MBq}$ of ${ }^{51} \mathrm{Cr}$ chromate, and readministered to the patient (10). The radioactivity of the pooled collections of gastric juice was measured in an Armac ${ }^{\circledR}$ large volume gamma counter (NV Packard Instruments Brussels, Belgium). Ten $\mathrm{ml}$ of blood was withdrawn daily and used as standard. The haemoglobin content of the blood was measured daily by the HiCN method in a Coulter S instrument (Hoek-Loos BV, Schiedam, The Netherlands). The results of the ${ }^{51} \mathrm{Cr}$-labelling studies, expressed in $\mathrm{ml}$ blood per 1 gastric aspirate, were converted to mmol $\mathrm{Hb}$ per $\mathrm{l}$ aspirate using the $\mathrm{Hb}$ concentration of peripheral blood on the morning of the collection day.

\section{Fluorimetric method of haemoglobin determination}

This method is based on that described by Schwartz et al. $(6,7)$ in which haem is broken down to iron and porphyrins (mainly dicarboxylic porphyrins such as protoporphyrin) by heating with oxalic acid and $\mathrm{FeSO}_{4}$, but is modified in that the resulting porphyrin is extracted from the reaction mixture by isopropanol.

\section{Reagents}

Crystalline haemoglobin was obtained from Sigma, St. Louis, Mo, USA. Haemoglobin stock standard was made by dissolving $20 \mathrm{mg}$ of haemoglobin in $10 \mathrm{ml} 9 \mathrm{~g} / \mathrm{l} \mathrm{NaCl}$, corresponding to $124 \mu \mathrm{mol} / \mathrm{l}$ haemoglobin. The following dilutions were made with $9 \mathrm{~g} / 1 \mathrm{NaCl}: 1: 20,1: 10,1: 5,1: 2.5$ and these, together with undiluted stock standard were used as standards for the assay.

\section{Oxalic acid reagent}

2.5 mol oxalic acid $\left(315 \mathrm{~g} \mathrm{C}_{2} \mathrm{H}_{2} \mathrm{O}_{4}, 2 \mathrm{H}_{2} \mathrm{O}\right), 90 \mathrm{mmol}(25 \mathrm{~g})$ $\mathrm{FeSO}_{4} \cdot 7 \mathrm{H}_{2} \mathrm{O}, 50 \mathrm{mmol}(8.4 \mathrm{~g})$ uric acid, $50 \mathrm{mmol}(9.1 \mathrm{~g})$ mannitol in bidistilled water to 11 , was made fresh each day and heated to $80^{\circ} \mathrm{C}$ on a thermostated hotplate while being mixed constantly with a magnetic stirrer, during 1 hour, before use. The reagent remains as a suspension, and was kept at $80^{\circ} \mathrm{C}$ while being stirred until use. A separate volume of reagent, kept at room temperature, was used for the blank determination of each sample.

\section{Procedure}

Collections of gastric juice were mixed well before sampling. In specimens where the contents did not form a homogenous suspension, a solution could be achieved by the addition of $\mathrm{NaOH}$. For the assay, $50 \mu \mathrm{l}$ of gastric juice was mixed with $50 \mu \mathrm{l}$ of $9 \mathrm{~g} / \mathrm{l} \mathrm{NaCl}$ in a polypropylene test tube. To this mixture
$2 \mathrm{ml}$ of reagent $\left(80^{\circ} \mathrm{C}\right)$ was added by means of a graduated $2 \mathrm{ml}$ glass pipctte and the tube placed in a waterbath at $100^{\circ} \mathrm{C}$ with a marble on top to prevent evaporation losses. After 30 min at $100^{\circ} \mathrm{C}$ the tubes were cooled under running tap water and $2 \mathrm{ml}$ of isopropanol was added when cooled. The contents were then mixed on a vortex mixer followed by centrifugation at $1200 \mathrm{~g}$ for 10 minutes. The supernatants were then transferred to a Perkin Elmer spectrofluorimeter (type 2000) (Perkin-Elmer Nederland BV, Gouda, The Netherlands) with a red-sensitive photomultiplier, and the fluorescence read at $399 \mathrm{~nm}$ excitation and $598 \mathrm{~nm}$ emission wavelengths.

Standards were run in a similar way by mixing $50 \mu$ of each haemoglobin standard with $50 \mu \mathrm{l} 0.01 \mathrm{~mol} / 1 \mathrm{HCl}$. Recoveries were determined by adding $50 \mu \mathrm{l}$ haemoglobin standard to $50 \mu \mathrm{l}$ sample.

A blank was prepared of each sample and standard. The order of addition of reagents to blanks was first the isopropanol $(2 \mathrm{ml})$, followed by the oxalic acid reagent $\left(2 \mathrm{ml} \mathrm{at} 20^{\circ} \mathrm{C}\right)$. This mixture was left at room temperature for 30 minutes. Centrifugation and subsequent measurements were then carried out as described above.

The fluorescence of the sample minus fluorescence of the sample blank was compared with the fluorescence curve of the standards minus standard blank. Recoveries were performed by adding $50 \mu \mathrm{l}$ of the $1: 5$ haemoglobin standard to $50 \mu \mathrm{l}$ of sample. Reproducibility was checked by performing the test on two series of multiple assays on separate days. All determinations were done in duplicatè. Completeness of extraction of porphyrins was checked by measuring the recovery of added protoporphyrin IX (obtained as disodium salt from Pfaltz \& Bauer, Flushing, NY, USA) in concentrations ranging from 11.4 to $114 \mu \mathrm{mol} / 1$ in gastric aspirates from 3 patients.

\section{HPLC of porphyrins}

The nature of the porphyrins, formed by heating gastric aspirates with the oxalic acid reagent and extracted from the mixture into isopropanol, was examined by reversed phase high performance liquid chromatography (11).

\section{Results}

\section{Recovery and reproducibility}

The isopropanol extraction method was found to extract all added protoporphyrin (recovery $100.3 \pm$ $5.4 \%$ ). Mean recovery of haemoglobin added to gastric aspirates was $92 \%$ (variation coefficient $9 \%$, $\mathrm{n}=52$ ). Reproducibility was good, e. g. two samples gave $11.86 \pm 0.95$ (mean $\pm \mathrm{SD}, \mathrm{n}=8$ ) and 51.48 $\pm 3.39(n=6) \mu \mathrm{mol} / \mathrm{l}$ haemoglobin.

\section{Comparison with ${ }^{51} \mathrm{Cr}$-labelled erythrocytes method}

The results of the comparison of the fluorescent method and the radiolabelled erythrocytes method for the 211 gastric aspirate samples is shown in figure 1. A good correlation was found over a wide range of concentrations. 


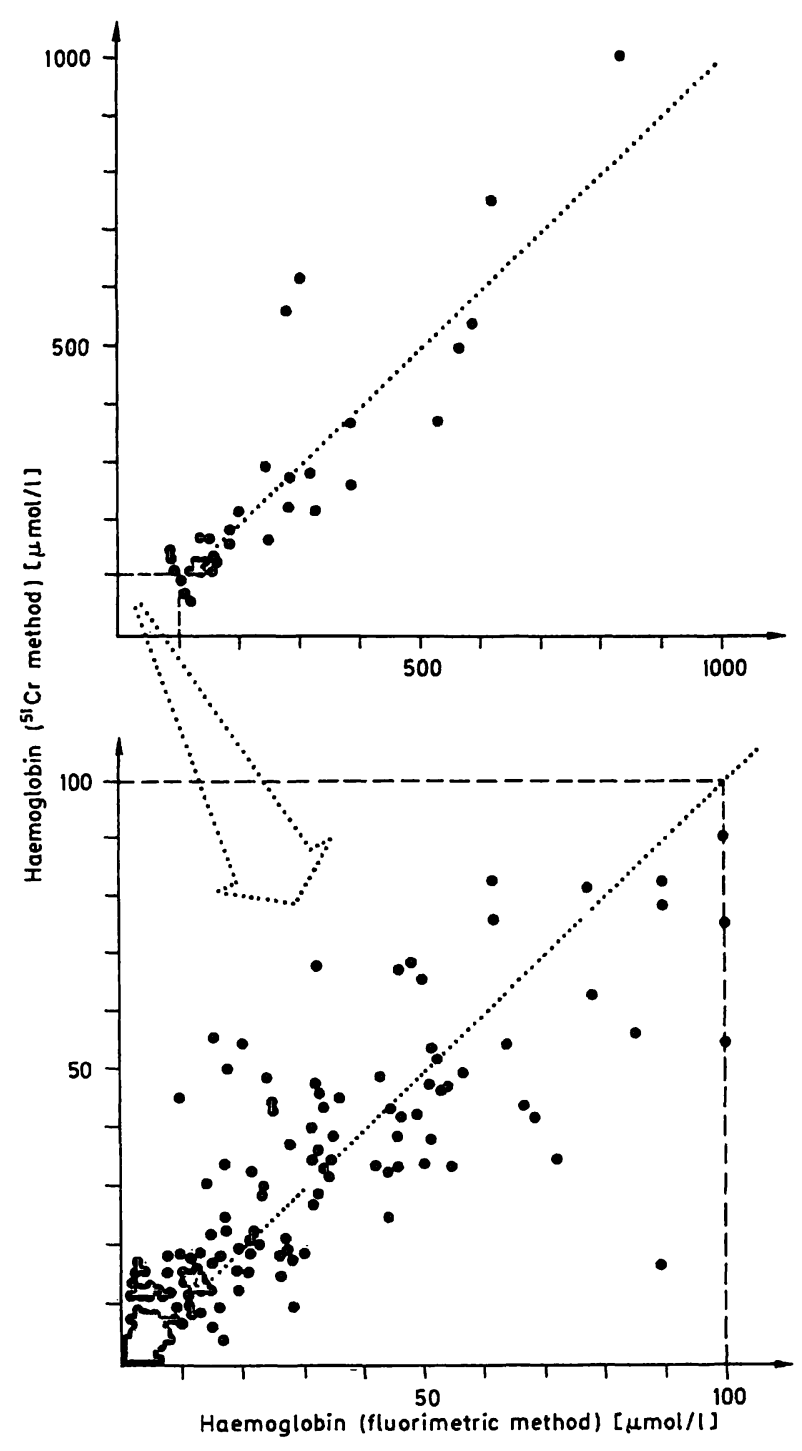

Fig. 1. Comparison of haemoglobin concentration in gastric erythrocytes. The dotted line represents the line of identity

$(y=1.03 x-0.25 ; r=0.042, p<0.001)$. aspirates measured fluorimetrically or by ${ }^{51} \mathrm{Cr}$-labelled

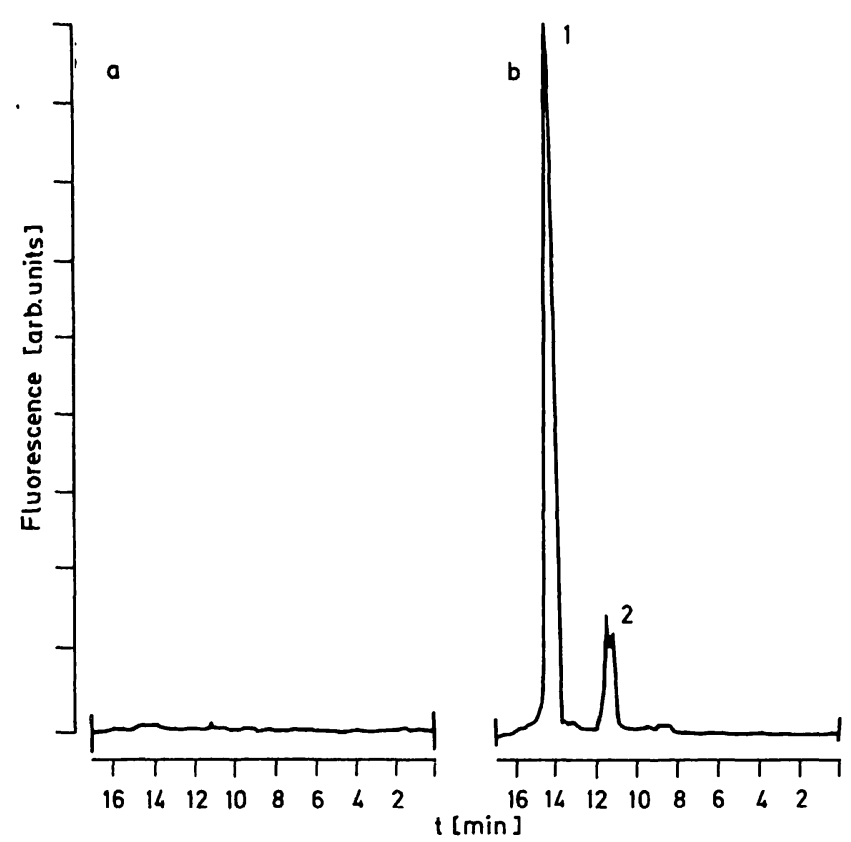

Fig. 2. HPLC chromatograms of the porphyrins formed by acid reduction of haemoglobin in a gastric aspirate (b), compared with the blank of the same gastric aspirate (a) .

Protoporphyrin is eluted at 14 min (peak 1), haematoporphyrin between 10 and 12 min (peak 2 ).

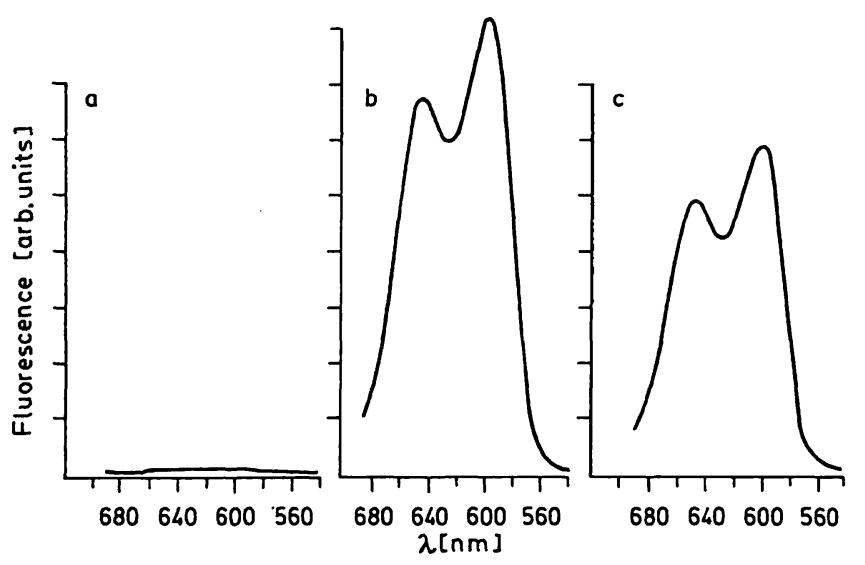

Fig. 3. Fluorescence emission spectra of the isopropanol extract of the blank of a gastric aspirate (a), a treated gastric aspirate (b) and the treated haemoglobin standard (c) (excitation wavelength $399 \mathrm{~nm}$ ).

\section{HPLC of fluorescent products}

Chromatograms of the porphyrins formed from gastric aspirates and extracted by isopropanol are shown in figure 2. Most porphyrins found under both situations are dicarboxylic porphyrins - mainly protoporphyrin. There was almost no detectable fluorescence in the blank determination of the specimen.

The fluorescence emission spectra for treated haemoglobin, gastric aspirate and blank are shown in figure 3.

\section{Discussion}

The fluorimetric method of determining haemoglobin in faeces has been reported to be quantitative and accurate over a wide range of haemoglobin concentrations $(6,7)$, and this we could confirm. In this study, measuring haemoglobin in gastric aspirates, we simplified the method described by Schwartz et al. (6) for faeces by reducing the extraction of porphyrins 
after the acid reduction to a single step. Isopropanol extracts mainly the lipid soluble porphyrins such as the dicarboxylic porphyrins which are formed when iron is removed from haem. This single extraction step has proved reliable for measuring haem (haemoglobin) in gastric aspirates, and preliminary studies suggest that it is also applicable to faeces, and that even for faeces there is negligible interference by endogenous porphyrins (except in patients with protoporphyria) or by chlorophyll.

This study shows a good correlation between this new quantitative test of gastric blood loss and the accepted test which uses radiolabelled erythrocytes. The differences in individual values between the two tests in this series could be due to problems in small scale sampling because of the inhomogeneity of gastric juice, and to the difficulties in measuring low levels of blood loss accurately with the radiolabelling technique due to the small amounts of ${ }^{51} \mathrm{Cr}$ in the samples. Blood in gastric aspirates is not distributed evenly, and it is sometimes difficult to obtain a homogenized mixture. Alkaline dilution, however, promotes solubilisation of proteins and haemoglobin and facilitates sampling. The good agreement found in this direct comparison of the two methods suggests that the technically simpler fluorimetric method can be used instead of the radiolabelling technique in clinical studies or clinical practice where detection and quantitation of gastric blood loss is needed. It is suitable for subjects in whom radioisotope studies are contraindicated.

\section{Acknowledgement}

We are grateful to Mr. P. P. M. Kooij and Mr. W. H. Bakker of the Department of Nuclear Medicine for their assistance and advice.

\section{References}

1. Hastings. P. R., Skillman, J. J., Bushnell, L. S. \& Silen, W. (1978) N. Engl. J. Med. 298, 1041-1045.

2. Priebe. H. J., Skillman, J. J., Bushnell, L. S., Long, P. C. \& Silen, W. (1980) N. Engl. J. Med. 302, 426-430.

3. Zinner, J. J., Zuidema, G. D., Smith, P. L. \& Mignosa, M. (1981) Surg. Gynecol. Obstet. 153, 214-220.

4. Pingleton, S. \& Hadzima, S. K. (1983) Crit. Care Med. 11, $13-16$.

5. Layne, E. A., Mellow, M. H. \& Lipman, T. O. (1981) Ann. Intern. Med. 94, 774-776.

6. Schwartz, S., Dahl, J., Ellefson, M. \& Ahlquist, D. (1983) Clin. Chem. 29, $2061-2067$.

7. Ahlquist, D. A., McGill, D. B., Schwartz, S., Taylor, W. F., Ellefson, M. \& Owen, R. A. (1984) Ann. Intern. Med. 1.01, $297-302$.

8. Morrison, G. R. (1965) Anal. Chem. 37, 1124-1126.

9. Van Essen, H. A., van Blankenstein, M., Wilson, J. H. P., van den Berg, B. \& Bruining, H. A. (1985) Crit. Care Med. 13, 957-960.

10. International Committee for Standardisation in Hematology. Recommended methods for radioisotope red cell șurvival studies (1971) Blood 38, 378-386.

11. Ford, R. E., Ou, C. N. \& Ellefson, R. D. (1981) Clin. Chem. 27, 397-401.

Prof. J. H. P. Wilson

Dept. of Internal Medicine II

University Hospital Dijkzigt

Dr. Molewaterplein 40

NL-3015 GD Rotterdam 